\title{
TINJAUAN FILOSOFIS UNDANG-UNDANG NOMOR 1 TAHUN 1974
}

\author{
Oleh \\ Tri Lisiani Prihatinah \\ Fakultas Hukum Universitas Jenderal Soedirman Purwokerto \\ tlisiani@yahoo.com
}

\begin{abstract}
In the globalization era, there is less respect to the marriage institution due to the influence from different concepts of marriages from different countries. In the Indonesian context, one of the reasons comes from misunderstanding towards the nature of family law i.e. Marriage Law Number 1 Year 1974. Better understanding for all Indonesian to the law from phylosophical point of view is an essential effort to achieve the goal of marriage itself. A specific analysis has been given to the aspects of onthology, epistemology and actiology.
\end{abstract}

Kata kunci: filsafat, UU Perkawinan, Indonesia

\section{A. Pendahuluan}

Agar maksud untuk memaknai hukum dapat tercapai, maka perlu memahaminya secara mendalam terhadap keberadaan hukum itu sendiri. Sehingga dapat ditemukan hakekat sebenarnya dari hukum itu sendiri, tujuannya dan mengapa orang harus tunduk pada hukum tersebut. Dengan pengertian yang tepat dalam memaknai hukum, diharapkan akan terjadi penghormatan terhadap hukum tersebut dan juga menimbulkan semangat untuk membangun suatu negara hukum yang lebih baik kalau tidak dapat dikatakan hukum yang sempurna. Oleh Theo Huijbers pemahaman yang mendekati sempurna terhadap hukum itu sendiri dipercaya sebagai hal yang dapat memperpendek jarak antara hukum dan keadilan sehingga hukum dipandang sebagai cita-cita yang harus dilaksanakan. ${ }^{1}$

Kehidupan saat ini banyak dipertanyakan relevansi kehidupan berkeluarga atas dasar pernikahan, hal ini menunjukkan adanya keraguan terhadap kehidupan berkeluarga yang dibangun diatas fondasi perkawinan. Dengan mempertimbangkan adanya keraguan ini, maka perlu dua hal mendasar yang harus dikupas yaitu memaknai keluarga dan memaknai perkawinan.

Dalam sistem hukum positif di Indonesia, maka keluarga dan perkawinan diatur dalam

\footnotetext{
1 Theo Huijbers, 1995, Filsafat Hukum, Yogyakarta: Kanusius, hlm. 11
}

Undang-Undang Nomor 1 Tahun 1974, sehingga untuk menipiskan keraguan akan makna keduanya perlu dibedah UU tersebut dari aspek filosofisnya. Hal ini karena UU tersebut merupakan norma hukum yang berlaku mengikat untuk semua Warga Negara Indonesia dimana pun berada. Dalam artikel ini akan dikupas bagaimana telaah filsafat hukum terhadap hakikat makna keluarga dan perkawinan dengan keyakinan bahwa pendekatan filsafat akan dapat mengupas sedalam-dalamnya hukum yang mengatur keluarga dan perkawinan. Beberapa aspek filsafat hukum dipaparkan dalam artikel ini yaitu aspek ontologi, epistimologi dan aksiologi dari kehidupan berkeluarga dan perkawinan. ${ }^{2}$ Dengan kajian filsafat hukum ini diharapkan akan diperoleh pemahaman yang lebih baik mengenai makna filosofis keluarga dan perkawinan.

\section{B. Pembahasan}

Uraian berikut akan membahas tiga hal yaitu makna keluarga, makna perkawinan, pengaturan perkawinan oleh negara, dan peran filsafat dalam hukum keluarga.

\section{Makna keluarga}

Tuhan sengaja menciptakan keluarga agar tercapai keteraturan buat manusia. Keluarga ini

\footnotetext{
2 Abdul Ghafur Ansori, Pidato Pengukuhan Guru Besar Fakultas Hukum UGM,, "Orientasi Nilai Filsafat Hukum Keluarga: Refleksi Undang-Undang Nomor 1 Tahun 1974 Tentang Perkawinan", hlm.9. 12 Desember 2005
} 
lahir sebagai konsekuensi dari fitrah manusia yang memiliki hubungan daya tarik menarik antara dua jenis manusia yaitu laki-laki dan perempuan. Pengingkaran terhadapnya mempunyai arti pengingkaran terhadap hukum alam yang diciptakan Tuhan. Sebagaimana firmannya dalam Qur'an berikut.

"Dan diantara tanda-tanda kebesaranNYA adalah bahwa menjadikan untukmu pasangan-pasangan dari kalanganmu sendiri supaya kamu cenderung dan merasa tenteram terhadapnya (sakinah) dan dijalaninya rasa kasih (mawaddah) dan sayang diantaramu (rahmah). Sesungguhnya pada yang demikian itu terdapat tanda-tanda bagi kaum yang berpikir" (Q.S.Ar-Rum:21). "Alloh menjadikan bagi kamu pasangan-pasangan dari kalanganmu sendiri dan menjadikan bagimu dari pasangan-pasanganmu itu anak-anak dan cucu-cucu dan memberi rejeki dari yang baik-baik. Maka mangapakah mereka beriman kepada yang batil dan mengingkari nikmat Alloh?” (Q.S.An-Nahl:72)

Hubungan dalam keluarga ini terdapat makna pembinaan dan pengaturan, sepadan dengan kata ummat (masyarakat) yang dimaknai sebagai tatanan hubungan antar orang (manusia) yang tertib dan teratur. ${ }^{3}$ Keluarga merupakan unit terkecil yang akan membentuk masyarakat Karakter masyarakat tercermin dalam kehidupan keluarga-keluarga dalam masyarakat. Kesejahteraan lahir dan batin yang dinikmati suatu bangsa adalah cerminan dari keadaan keluarga-keluarga yang hidup pada masyarakat bangsa tersebut. ${ }^{4}$

\section{Makna Perkawinan}

Perkawinan atau pernikahan sangat penting dalam kehidupan manusia karena dengan perkawinan yang sah mengakibatkan pergaulan antara laki-laki dan perempuan menjadi terhormat sesuai dengan kedudukan manusia sebagai mahluk yang terhormat. Pergaulan hidup berumah tangga dibina dalam suasana damai, tentram dan kasih sayang antara suami dan istri. Sementara anak hasil keturunan

\footnotetext{
3 Abdul Manan, 2005, Aspek-Aspek Pengubah Hukum, Jakarta: Prenada Media, hlm. 4

4 Quraish Shihab, 1994, Membumikan Al-Qur'an, Bandung: Mizan, hlm. 255
}

perkawinan sah yang menghiasi kehidupan berumah tangga merupakan perhiasan kehidupan berumah tangga sekaligus merupakan kelangsungan hidup manusia secara bersih dan terhormat.

Hukum Islam memandang hubungan seksual sebagai sesuatu yang sakral, oleh sebab itiu pernikahan bukan semata-mata sebagai sakramen melainkan kontrak yang dibuat oleh kedua belah pihak. $^{5}$ Sehingga dalam memandang hubungan seksual tersebut tetap berlaku asas umum perjanjian yaitu salah satunya adanya kesepakatan kedua belah pihak. ${ }^{6}$ Menurut Imam Syafi'i pengertian nikah adalah suatu akad yang dengannya menjadi halal hubungan seksual antara laki-laki dengan perempuan. Sedangkan menurut arti majazi (methaporic) nikah itu artinya hubungan seksual. ${ }^{7}$ Menurut Sajuti Thalib perkawinan adalah menciptakan kehidupan keluarga antara suami istri dan anak-anak serta orang tua agar tercapai suatu kehidupan yang aman tentram (sakinah), pergaulan yang saling mencintai (mawaddah) dan salin menyantuni (rahmah). ${ }^{8}$

Sehingga dapat diterima alasan rasional bahwa Islam mengatur masalah perkawinan dengan teliti dan terinci dengan tujuan untuk membawa umat manusia pada kehidupan yang terhormat sesuai dengan kedudukannya yang mulia diantara mahluk-mahluk Tuhan yang lainnya. Berbeda dengan mahluk lain, hewan misalnya yang tidak terikat pada aturan terinci tentang perkawinan, walaupun keduanya memiliki insting dasar untuk memenuhi kebutuhan biologis mereka. Hubungan manusia laki-laki dan perempuan didasarkan pada rasa pengabdian kepada Allah sebagai Al-Khaliq (Tuhan Maha Pencipta) dan berbakti kepada manusia guna melangsungkan kehidupan jenisnya. Perkawinan didasarkan pada kerelaan pihak-pihak yang bersangkutan, yang tercermin dari keten-

\footnotetext{
5 Seyyed Hossein Nasr, 2003, Islam: Agama Sejarah dan Peradaban, Surabaya: Risalah Gusti, hlm. 80

6 Abdul Ghofur Anshori, 2006, Pokok-Pokok Hukum Perjanjian Islam di Indonesia, Yogyakarta: Citra Media, hal. 26

7 Ibrahim Hosen, 1971, Fiqih Perbandingan dalam Masalah Nikah dan Rujuk, Jakarta: Ilya Ulumudin, hal. 65

8 Sajuti Thalib, 1974, Hukum Kekeluargaan Indonesia, Jakarta: UI Press, hal. 47
} 
tuan-ketentuan yang ada misalnya peminangan, ijab qobul, saksi, wali dan perhelaan (walimah). ${ }^{9}$ Hak dan kewajiban suami istripun diatur didalamnya, demikian juga hak dan kewajiban sebagai anak dan orang tua. Sehingga jika terjadi perselisihan, sudah ada pedoman penyelesaiannya.

Tujuan perkawinan menurut perintah Allah adalah untuk memperoleh keturunan yang sah dalam masyarakat melalui dibentuknya rumah tangga yang damai dan teratur. ${ }^{10}$ Sedangkan tujuan perkawinan dalam Islam selain untuk memenuhi kebutuhan hiudp jasmani dan rohani manusia, juga sekaligus untuk membentuk keluarga dan memelihara serta meneruskan keturunan dalam menjalani hidup di dunia ini, selain mencegah perzinahan, agar tercipta ketenangan dan ketentraman jiwa bagi yang bersangkutan, ketentraman keluarga dan masyarakat. ${ }^{11}$

Imam Ghazali seperti dikutip oleh Soetiksno membagi tujuan dan faedah perkawinan menjadi lima hal yaitu:

a. memperoleh keturunan yang sah yang dalam melangsungkan keturunan serta perkembangan suku-suku bangsa manusia,

b. memenuhi tuntutan naluriah hidup manusia,

c. memelihara manusia dari kejahatan dan kerusakan,

d. membentuk dan mengatur rumah tangga yang menjadi basis pertama dari masyarakat yang besar di atas dasar kecintaan dan kasih sayang, dan

e. menumbuhkan kesungguhan berusaha mencari rejeki penghidupan yang halal dan memperbesar rasa tanggungjawab.

Atas dasar uraian tersebut dapat disimpulkan bahwa hukum perkawinan mempunyai kedudukan amat penting dalam Islam karena hukum perkawinan mengatur tata cara kehidupan keluarga yang merupakan inti kehidupan masyarakat sejalan dengan keduduk-

\footnotetext{
9 Ahmad Ashar Basir, 1999, Hukum Perkawinan, Yogyakarta: UII Press, hal. 1

${ }^{10}$ Mahmud Yunus, 1996, Hukum Perkawinan dalam Islam, Jakarta: CV Al-Hidayah, hlm. 1

${ }^{11}$ Mohd Idris Ramulyo, 2004, Hukum Perkawinan Islam: Suatu Analisis dari UU Nomor 1 Tahun 1974 dan Kompilasi Hukum Islam, Bandung: Citra Aditya, hlm. 27
}

an manusia sebagai mahluk yang terhormat melebihi mahluk-mahluk Tuhan yang lainnya. Hukum perkawinan merupakan bagian dari ajaran agama Islam yang wajib ditaati dan dilaksanakan sesuai ketentuan-ketentuan yang terdapat dalam ketentuan agama.

\section{Pengaturan Perkawinan oleh Negara}

Di Indonesia terdapat hukum positif yang mengatur tentang perkawinan yaitu undangundang nomor 1 tahun 1974. Apabila dicermati pasal-demi pasal undang-undang tersebut maka diharapkan hubungan manusia yang berkaitan dengan perkawinan dapat berlangsung dengan tertib. Dengan demikian jika manusia melaksanakan pasal-pasal dalam UU tersebut dapat diartikan manusia melaksanakan nilainilai ideal kemanusiaan. Seperti disebutkan dalam Pasal 1 UU Perkawinan tersebut tentang definisi perkawinan tersebut dituliskan bahwa, 'Perkawinan adalah ikatan lahir batin antara seorang pria dan seorang wanita sebagai suami istri dengan tujuan membentuk keluarga (rumah tangga) yang bahagia yang kekal berdasarkan Ketuhanan Yang Maha Esa'. Bunyi pasal ini menandakan bahwa perkawinan bukan hanya dipandang sebagai ikatan perdata saja tetapi mengandung dimensi religi. Berbeda dengan konsep perkawinan seperti yang diatur dalan Kitab Undang-undang Hukum Perdata khususnya Pasal 26 KUHPerdata yang memandang soal perkawinan hanya dalam hubungan-hubungan perdata saja.

Selanjutnya diatur dalam Pasal 3 UUP bahwa pada asasnya dalam suatu perkawinan seorang pria hanya boleh mempunyai seorang istri, Seorang perempuan hanya boleh mempunyai seorang suami. Hal ini sesuai dengan firman Tuhan dalam Kitab Suci bahwa:,' ... dan jika kamu takut tidak akan dapat berlaku adil terhadap (hak-hak) perempuan yatim, maka kawinilah wanita-wanita (lain) yang kamu sukai: dua, tiga atau empat. Kemudian jika kamu takut tidak akan dapat berlaku adil, maka (kawinilah) seorang saja...'. (Q.S. An Nisa:3).

Ayat tersebut sebetulnya merupakan pembatasan pada bentuk perkawinan monogami. Perintah untuk mengawini lebih dari satu 
bukan merupakan perintah yang bersifat imperatif, namun yang bersifat fakultatif. ketika tidak mampu berlaku adik kepada perempuan yatim yang dikawini.. Bahkan mengawini perempuan yang bukan anak yatimpun dibatasi hanya seorang saja jika tidak mampu berbuat adil. Ini berarti unsur keadilan merupakan hal yang mutlak dalam kehidupan berkeluarga. Oleh karena itu perintah mengawini seorang saja lebih kuat, walaupun dalam hal ini Islam memberikan peluang kepada seorang laki-laki untuk menikah lebih dari satu dengan syarat yang berat yaitu mampu berlaku adil.

Sejalan dengan ketentuan tersebut Undang-undang Perkawinan juga membolehkan seorang laki-laki untuk menikahi lebih dari satu wanita dengan syarat yang berat pula yakni:

a. istri tidak dapat menjalankan kewajibannya sebagai istri

b. istri mendapat cacat badan atau penyakit yang tidak dapat

disembuhkan

c. istri tidak dapat melahirkan keturunan.

Selanjutnya untuk dapat mengajukan permohonan kepada pengadilan harus dipenuhi syarat-syarat komulatif sbb:

a. adanya persetujuan dari istri atau para istri

b. adanya kepastian bahwa suami mampu menjamin keperluan keperluan hidup istriistri dan anak-anak mereka

c. adanya suatu jaminan bahwa suami akan berlaku adil terhadap istri-istri dan anakanak mereka.

Ketentuan tersebut sudah ideal bagi suatu pembatasan mengigat persyaratan yang diberikan sudah teramat berat. Kelonggaran untuk melakukan poligami hanya bisa diberikan ketika istri tidak dapat menjalankan tugas sebagai istri, cacat fisk/ penyakit yang tidak dapat disembuhkan atau istri tidak dapat melahirkan keturunan. Hal ini dikarenakan tujuan perkawinan adalah membentuk rumah tangga yang bahagia, maka ketiga hal tersebut mungkin bagi sebagian orang sulit dicapai. Oleh karena itu UU perkawinan memberikan peluang untuk beristri lebih dari satu.
Mengenai hak dan kewajiban suami istri diatur dalam Pasal 31 UUPerkawinan. Hak dan kedudukan istri adalah seimbang dengan hak dan kedudukan suami dalam kehidupan berrumah tangga dan pergaulan hidup bersama dalam masyarakat. Masing-masing pihak berhak untuk untuk melakukan perbuatan hukum, berbeda dengan yang diatur dalam KUHPerdata bahwa seorang perempuan yang telah kawin pada umumnya tidak diperbolehkan bertindak sendiri dalam hukum, tetapi harus dibantu suaminya. (Pasal 108 KUHPerdata). la yang oleh hukum dianggap kurang cukup untuk bertindak sendiri. ${ }^{12}$ Dengan demikian UU Perkawinan jauh lebih maju dibandingkan dengan KUHPerdata. Bertitik tolak pada alasan tersebut UUP menghapus ketentuan berlakunya KUHPerdata berdasarkan adagium lex posteriori derogate legi priori.

Suami istri wajib saling cinta-mencintai, hormat menghormati, setia dan memberi bantuan lahir batin yang satu kepada yang lainnya. (Pasal 33 UUPerkawinan). Suami adalah kepala keluarga dan istri ibu rumah tangga (Pasal 31 UUP). Suami diberkewajiban oleh UU untuk melindungi istrinya dan memberikan segala sesuatu keperluan hidup berumah tangga sesuai dengan kemampuan suami. Demikian juga istri yang diwajibkan oleh UU untuk mengatur urusan rumah tangga sebaik-baiknya. (Pasal 34 UUPerkawinan).

Tanggung jawab istri untuk mengatur urusan rumah tangga sebaik-baiknya, bukan berarti membakukan peran perempuan hanya pada ranah domestik, dan laki-laki pada ranah publik. Demikian pula kedudukan suami sebagai kepala keluarga, bukan berarti kedudukan perempaun berada di bawah kedudukan lakilaki. Sebagai institusi paling independen, keluarga memiliki otoritas absolut dalam mengatur perjalanan roda rumah tangganya. Tidak ada satupun kekuatan luar sekalipun itu pemerintah yang memiliki otoritas penuh untuk melakukan intervensi terhadap satu keluarga, kecuali atas ijin keluarga yang bersangkutan. Oleh karena itu jika dalan Pasal 34 ayat UUP

\footnotetext{
12 Subekti, 1996, Pokok-Pokok Hukum Perdata, Jakarta: Intermasa, hal.20
} 
hanya menyatakan jika suami istri melalaikan kewajibannya masing-masing dapat mengajukan gugatan ke pengadilan karena dipersalahkan melakukan tindak pidana melalaikan kewajiban-kewajiban tersebut.

Hanya saja patut disadari kenyataan bahwa Tuhan memang telah memberikan kelebihan kepada laki-laki sebagaimana difirmankan dalam Kitab Suci,'Kaum laki-laki adalah pemimpin bagi kaum wanita, oleh karena itu Alloh telah melebihkan sebagian mereka (lakilaki) atas sebagian yang lain (wanita), dan karena mereka (laki-laki) telah menafkahkan sebagian dari harta mereka. Sebab itu wanita yang saleh ialah yang taat kepada Allah lagi memelihara diri ketika suaminya tidak ada, oleh karena Allah telah memelihara (mereka)...(QS. An Nisa:34). Pembagian peran ini hanya berlaku dalam rumah tangga dan bukan meliputi kehidupan publik dan argumen inilah yang menepis bahwa perempuan tidak pantas menjadi pemimpim dalam ruang publik. Dengan demikian alasan nyata dalam relasi jender dalam keluarga adalah karena dia berjenis lakilaki yang perannya dianggap sudah melekat (inheren) di dalam jenis kelamin itu sendiri, sehingga secara otomatis ia harus bertanggungjawab dalam menafkahi keluarga.

Kewajiban untuk memelihara dan mendidik anak-anak mereka sebaik-baiknya merupakan kewajiban suami dan istri (Pasal 45 UUP). Kewajiban tersebut berlaku sampai anak itu kawin atau dapat berdiri sendiri dan kewajiban tersebut tetap terus menjadi tanggungjawab mereka meskipun perkawinan antara kedua orang itu putus. Hal ini disadari karena keluarga merupakan lembaga pendidikan yang sangat penting dalam pembentukan dan pengembangan karakter, kepribadian, etika, moral dan sopan santun. Keluarga juga menjadi institusi pendidikan nilai-nilai sosial dan religi bagi setiap anggotanya.

Dari sini dapat disimpulkan bahwa UU Nomor 1 Tahun 1974 tentang Perkawinan memuat nilai-nilai yang baik dan universal dan sesuai dengan Kitab Suci. Oleh karena itu sebaiknya nilai-nilai tersebut tidak hanya dapat direfleksikan sebagai nilai moral, etika semata, tetapi juga sebagai kewajiban hukum agama. Jadi dengan UU Nomor 1 Tahun 1974 ini negara berarti telah memainkan perannya untuk mengatur ketertiban masyarakat yang salah satu aspeknya adalah perkawinan.

\section{Peran Filsafat dalam Hukum Keluarga}

Seperti diketahui bahwa negara sudah mengatur tentang perkawinan dan hidup kekeluargaan, maka setiap orang perlu mengetahui hakikat keduanya. Untuk mengetahui hakikat keduanya dapat dilihat dari aspek ontologis, epistemologi dan aksiologi dari perkawinan dan hidup kekeluargaan. ${ }^{13}$

Aspek ontologi yaitu dapat dipahaminya hakikat hubungan antara manusia dengan nilainilai sebuah perkawinan dan keluarga yang dilakukan antara laki-laki dengan perempuan. Dalam kontek Indonesia maka hakikat dasar ontologi manusia yang mendasari makna hidup keluarga dan perkawinan adalah bersumber dari nilai-nilai Pancasila sebagaimana terdapat di dalam Pembukaan Undang-Undang Dasar 1945 yang menjadi grundnorm Negara Republik Indonesia. Sehubungan dengan itu, maka konsep ideal yang dicita-citakan berlangsung dalam keadaan serasi yang mencerminkan dapat dipenuhinya kebutuhan keluarga dan perkawinan yaitu kebutuhan yang berkaitan dengan:

a. pribadi/ individu

b. sosial

c. Tuhan

Sementara aspek epistemologi adalah upaya filosofis untuk memahami hakikat kebenaran dan pengetahuan yang dapat dicapai rasio manusia atas hukum keluarga dan perkawinan sehingga akan dapat dipelihara dengan baik sebagai sarana manusia untuk menunaikan kehidupannya di dunia. ${ }^{14}$

Aspek aksiologi berupaya mengetahui hakikat esensi nilai yang terdapat di dalam hukum keluarga. Fokus dari nilai disini adalah

\footnotetext{
13 Soetiksno, 2003, Filsafat Hukum Bagian 1, Jakarta: Pradnya Paramita, hlm. 17

14 Samson Rahman, 2007, Islam Moderat: Menebar Islam Rahmatan Lil Alamin, Jakarta: Pustaka IKADI, hal.13.
} 
mengenai baik dan buruk dari sudut pandang moral dan etika dan manfaat. Berpangkal dari keluarga yang terbentuk atas dasar perkawinan antara seorang laki-laki dengan seorang perempuan, kemudian menimbulkan hubungan keluarga yaitu dibedakan atas dasar keturunan darah maupun hubungan perkawinan. Demikian pula timbul hubungan kewarisan yang menjadi kepentingan negara untuk mengaturnya dalam hukum positif. Aspek aksiologi sebagai bagian dari filsafat sangat penting sebagai landasan ontologi manusia yang berimplikasi pada tatanan pengetahuan yang dihasilkannya.

Dalam UU Nomor 1 Tahun 1974 diatur tentang definisi perkawinan (Pasal 1) dan keabsahan perkawinan (Pasal 2) memiliki hubungan kebenaran korespondensi dengan filosofis ontologi manusia yang bersifat monopluralis. Seperti diungkapkan oleh almarhum Notonagoro bahwa landasan ontologis manusia yang monopluralis adalah landasan bagi Pancasila yang menjadi sebuah sistem filsafat, menjiwai segenap peraturan perundang-undangan di Republik Indonesia ini. Ini berarti kodrat manusia antara laki-laki dan perempuan untuk membentuk kehidupan keluarga yang bahagia telah diadopsi oleh UU Nomor 1 Tahun 1974. Pendefinisian perkawinan oleh UU yang mendasarkan keabsahan perkwinan bila dilakukan sesuai dengan hukum masing-masing agama dan kepercayaannya menunjukkan bahwa hukum keluarga Indonesia sesuai dengan nilai filosofis ontologi manusia monopluralis yang mengakui nilai religius yang bersifat mutlak. Sehingga dapat diartikan bahwa filsafat hukum keluarga akan berperan positif membangun hukum yang dibutuhkan masyarakat melaui dibentuknya perundang-undangan. ${ }^{15}$ Selain itu sekaligus memiliki tugas penting untuk mengembangkan sistem hukum nasional serta memberikan pemahaman yang benar akan makna setiap aturan hukum positif.

\section{Penutup}

Di Indonesia berlakunya UU Perkawinan Nomor 1 Tahun 1974 tidak bisa lepas dari aspek

\footnotetext{
${ }^{15}$ Soetiksno, 2003, Filsafat Hukum Bagian 1, Jakarta: Pradnya Paramita, hlm. 459
}

teologis pembentukannya. Sehingga tidak mengherankan banyak kesesuaian UU positif tersebut dengan ketentuan dalam Kitab Suci. Aspek yang diatur dalam UU tersebut adalah aspek ontologis, espistemologis dan aksiologis. Dengan pemahaman terhadap ketiga aspek tersebut diharapkan dapat diwujudkan ketentraman dan keadilan. Ketentuan dalam UU ini merupakan sarana mengatur tata tertib dalam kehidupan warga negaranya. Pemahaman individu terhadap nilai-nilai filosofis hukum perkawinan dan keluarga akan sangat menentukan baik buruknya hidup berkeluarga yang dibentuk atas dasar perkawinan. Nilai-nilai hukum keluarga termasuk pula nilai-nilai hidup perkawinan akan memberikan manfaat yang baik ketika seorang laki-laki dan perempuan dalam menjalani hidupnya berpegang pada nilai-nilai tersebut.

Indonesia sebagai negara yang berdaulat memiliki sistem hukumnya sendiri termasuk pengaturannya dalam masalah keluarga dan perkawinan. Hakikat dasar ontologi manusia yang mendasari makna hidup keluarga dan perkawinan bersumber pada nilai-nilai Pancasila sebagaimana terdapat di dalam pembukaan Undang-undang Dasar 1945 yang menjadi grundnorm Negara Republik Indonesia dan terjabarkan dalam pasal-pasal UU Perkawinan. Sehingga pemahaman hukum dari aspek filosofis sangat perlu agar tujuan dari berkeluarga melalui perkawinan tersebut dapat tercapai.

\section{Daftar Pustaka}

Anshori, Abdul Ghofur. 2006. Pokok-Pokok Hukum Perjanjian Islam di Indonesia. Yogyakarta: Citra Media;

Pidato Pengukuhan Guru Besar Fakultas Hukum UGM, "Orientasi Nilai Filsafat Hukum Keluarga: Refleksi Undang-Undang Nomor 1 Tahun 1974 tentang Perkawinan", 12 Desember 2005;

Basir, Ahmad Ashar. 1999. Hukum Perkawinan. Yogyakarta: UII Press;

Hosen, Ibrahim. 1971. Fiqih Perbandingan dalam Masalah Nikah dan Rujuk. Jakarta: Ilya Ulumudin; 
172 Jurnal Dinamika Hukum Vol. 8 No. 2 Mei 2008

Huijbers, Theo. 1995. Filsafat Hukum. Yogyakarta: Kanusius;

Tahun 1974 dan Kompilasi Hukum Islam. Bandung: Citra Aditya;

Manan, Abdul. 2005. Aspek-Aspek Pengubah Hukum. Jakarta: Prenada Media;

Nasr, Seyyed Hossein. 2003. Islam: Agama Sejarah dan Peradaban. Surabaya: Risalah Gusti;

Rahman, Samson. 2007. Islam Moderat: Menebar Islam Rahmatan Lil Alamin. Jakarta: Pustaka IKADI;

Ramulyo, Mohd. Idris. 2004. Hukum Perkawinan Islam: Suatu Analisis dari UU Nomor 1

Shihab, Quraish. 1994. Membumikan Al-Qur'an. Bandung: Mizan;

Soetiksno. 2003. Filsafat Hukum Bagian 1. Jakarta: Pradnya Paramita;

Subekti. 1996, Pokok-Pokok Hukum Perdata. Jakarta: Intermasa;

Thalib, Sajuti. 1974. Hukum Kekeluargaan Indonesia. Jakarta: UI Press;

Yunus, Mahmud. 1996. Hukum Perkawinan dalam Islam. Jakarta: CV Al-Hidayah. 